\title{
The correlation between body mass index, routine clinical and laboratory parameters and in-hospital survival in patients with acutely decompensated heart failure
}

\section{Teodora Zaninović Jurjevićc ${ }^{*}$, \\ Štefica Dvornik', Nikolina Jurjević \\ Andrica Lekić ${ }^{3}$, Luka Zaputović'}

'University of Rijeka School of Medicine, University Hospital Centre Rijeka, Rijeka, Croatia ${ }^{2}$ Primary Health Care Service of Primorsko-Goranska County, Rijeka, Croatia ${ }^{3}$ University of Rijeka Faculty of Health Studies, Rijeka, Croatia
RECEIVED:

September 21, 2017

ACCEPTED:

September 26, 2017

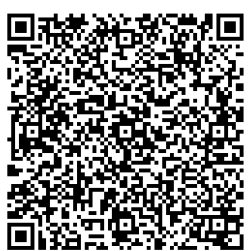

KEYWORDS: heart failure, body mass index, prognosis.

CITATION: Cardiol Croat. 2017;12(9-10):362. | https://doi.org/10.15836/ccar2017.362

*ADDRESS FOR CORRESPONDENCE: Teodora Zaninović Jurjević, Klinički bolnički centar Rijeka, T. Strižića 3, HR51000 Rijeka, Croatia. / Phone: +385-98-320-768 / E-mail: teazj@net.hr

ORCID: TeodoraZaninović Jurjević, http://orcid.org/0000-0001-8359-3910 • Štefica Dvornik, http://orcid.org/0000-0001-5295-7857 Nikolina Jurjević, http://orcid.org/0000-0003-2663-6843 • Andrica Lekić, http://orcid.org/0000-0002-6175-635X Luka Zaputović, http://orcid.org/0000-0001-9415-9618

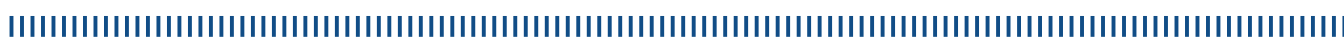

Introduction: Recent studies have investigated the existence of so-called "obesity paradox" in heart failure (HF) patients, suggesting that obese patients might have a better prognosis than underweight and normal weight patients. ${ }^{1}$ It seems that body mass index (BMI) may be an independent prognostic factor in patients with acute and chronic HF.

Patients and Methods: We investigated the correlation between BMI, in-hospital survival and routine clinical and laboratory parameters in patients hospitalized for acutely decompensated HF

Results: Total number of 145 patients (mean age $76 \pm 10.2$ years) were divided in three groups: 37 with normal body weight $\left(20-24.9 \mathrm{~kg} / \mathrm{m}^{2}\right)$, 64 overweight $\left(25-29.9 \mathrm{~kg} / \mathrm{m}^{2}\right)$, and 44 obese patients $\left(\geq 30 \mathrm{~kg} / \mathrm{m}^{2}\right)$ patients. At the end of approximately 9 days of hospitalization, 24 of all patients died (16.5\%). In-hospital mortality was significantly lower in obese patients (7\%; $\mathrm{p}=0.05)$. Patients with normal body weight were older than obese patients: 80 (75-87) compared to 72 (65-80); $p=0.001$ and significant negative correlation between BMI and patients age existed $(r=-0.383 ; p<0.001)$. There was no significant difference in left ventricular ejection fraction between three compared groups of patients. Obese patients had significantly lower NT-proBNP (pmol/1): 319 (182-758) compared to overweight 862 (342-3013) and compared to normal body weight 1209 (616-2378); p=0.001, hs-cTnT (ng/l): 23 (15-57) compared to overweight 38 (27-70) and compared to normal body weight 44 (29-60); $\mathrm{p}=0.009$ and serum urea (mmol/l) concentration: 8.1 (6.2-12.3) compared to overweight 9.7 (6.6-12.3) and compared do normal body weight 11.3 (8.2-14.7); $\mathrm{p}=0.039$. No significant difference in serum creatinine, uric acid and hemoglobin existed, but significant negative correlation between BMI and NT-proBNP was found $(r=-0.22 ; p=0.013)$

Conclusions: In-hospital mortality was significantly lower in obese HF patients. Obese patients had significantly lower NT-proBNP, hs-cTnT and serum urea concentrations. There was significant negative correlation between BMI and NT-proBNP.

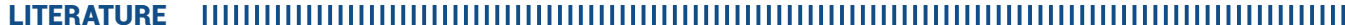

1. Shah R, Gayat E, Januzzi JL Jr, Sato N, Cohen-Solal A, diSomma S, et al; GREAT (Global Research on Acute Conditions Team) Network. Body mass index and mortality in acutely decompensated heart failure across the world: a global obesity paradox. J Am Coll Cardiol. 2014 Mar 4;63(8):77885. https://doi.org/10.1016/j.jacc.2013.09.072 